\title{
Application of Geomechanically-Based Fracture Models to a Fractured Chalk Field, Offshore Denmark
}

Welch, Michael; Lüthje, Mikael; Oldfield, Simon

Publication date:

2020

Document Version

Publisher's PDF, also known as Version of record

Link back to DTU Orbit

Citation $(A P A)$ :

Welch, M. (Author), Lüthje, M. (Author), \& Oldfield, S. (Author). (2020). Application of Geomechanically-Based Fracture Models to a Fractured Chalk Field, Offshore Denmark. Sound/Visual production (digital)

\section{General rights}

Copyright and moral rights for the publications made accessible in the public portal are retained by the authors and/or other copyright owners and it is a condition of accessing publications that users recognise and abide by the legal requirements associated with these rights.

- Users may download and print one copy of any publication from the public portal for the purpose of private study or research.

- You may not further distribute the material or use it for any profit-making activity or commercial gain

- You may freely distribute the URL identifying the publication in the public portal 
Application of Geomechanically-Based Fracture Models to a Fractured Chalk Field, Offshore Denmark 
- Large (c.8x5km) salt pillow

- Cut by NNE-SSW striking faults, mapped on seismic

- Main reservoir unit comprises fractured Danian chalk (Ekofisk Fm)

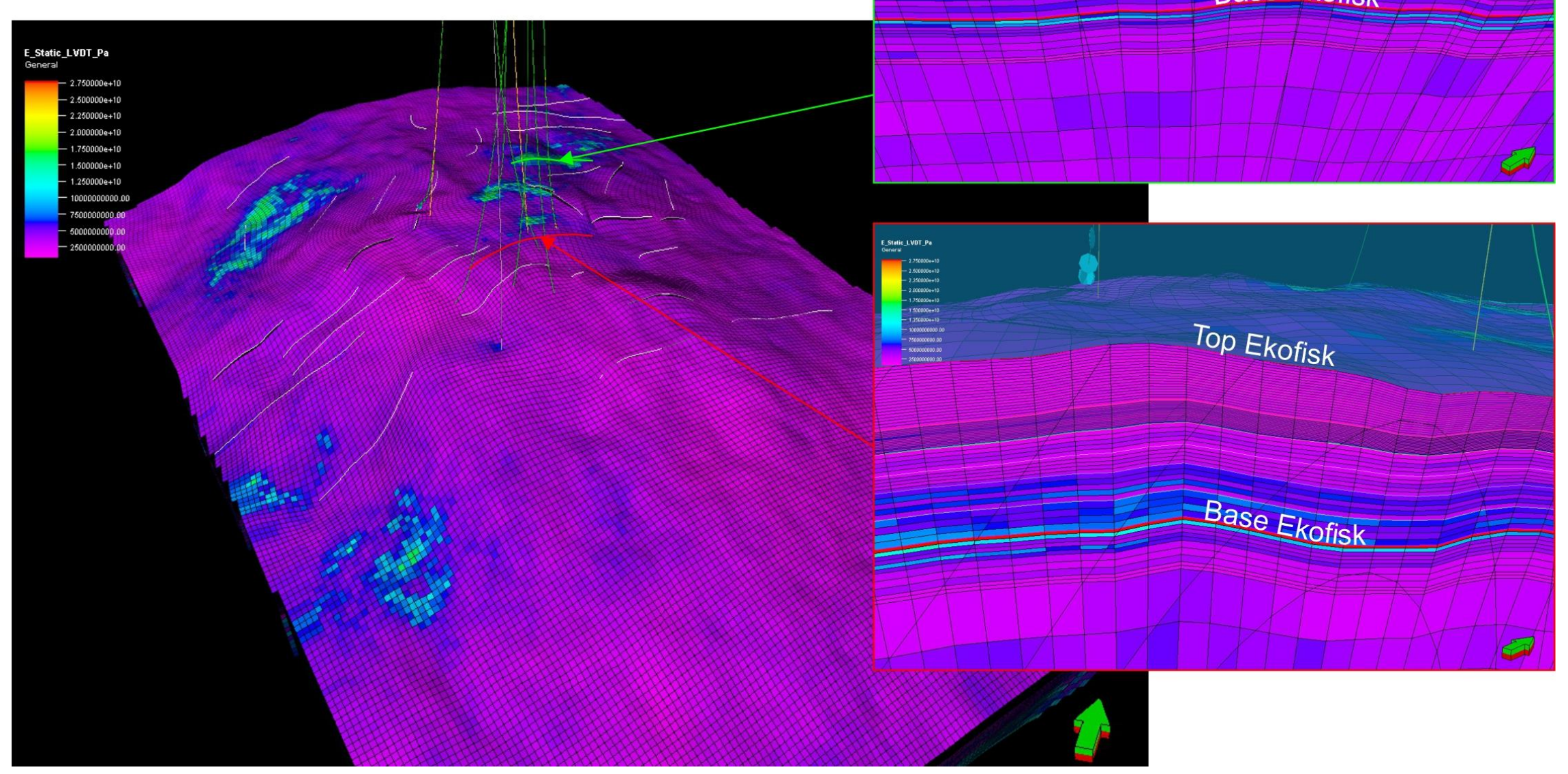


EAGE2020

ANNUAL CONFERENCE

\section{Fractures in the chalk}

Two types of fracture:

- A, B: Small (up to $50 \mathrm{~cm}$ ) fractures, often around stylolites or chert nodules. May enhance permeability locally.

- C: Large $(100 m+$ ?) open fractures, with cement and slickensides. May form major flow pathways.
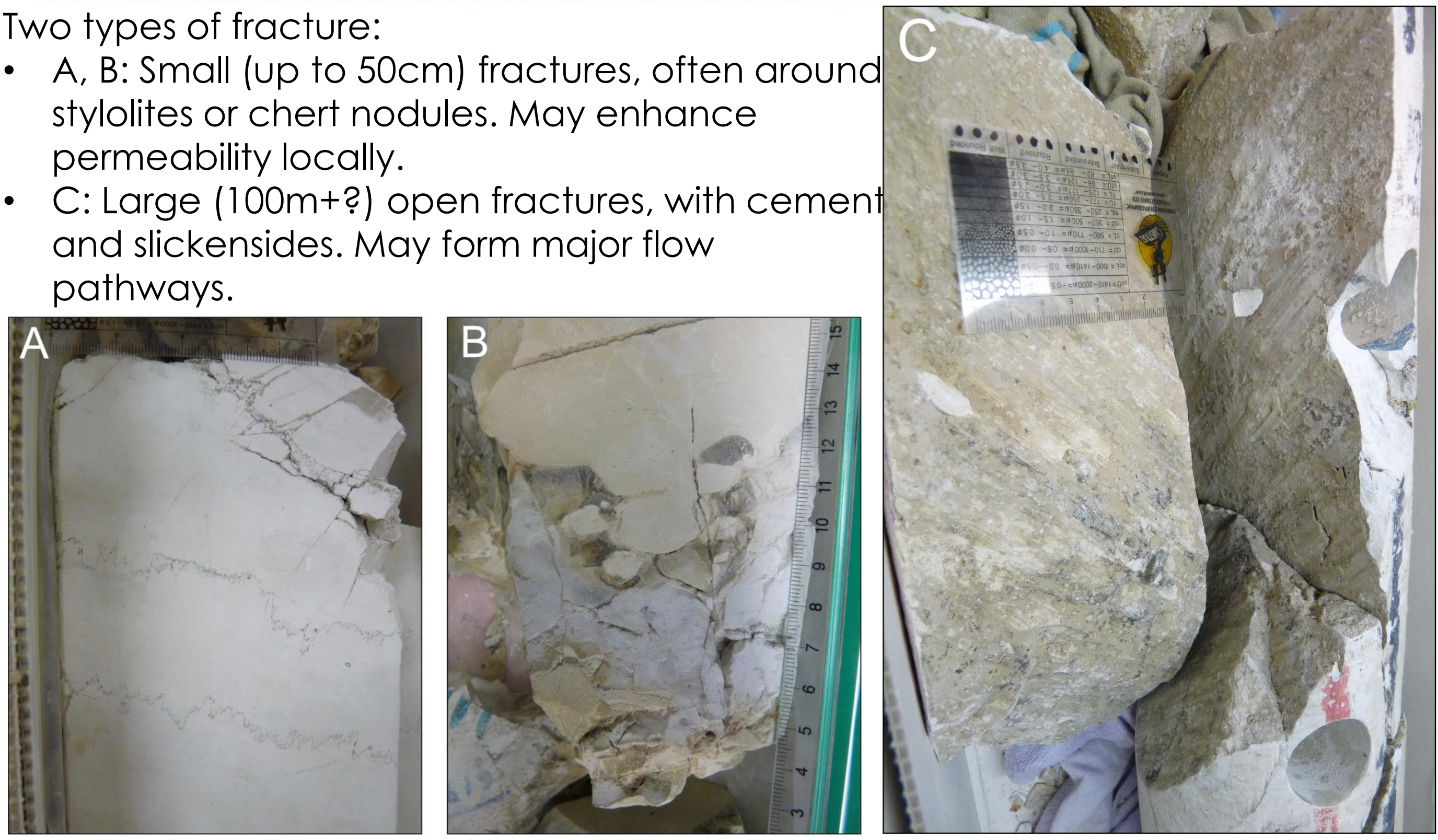


\section{Fracture orientations from $\mathrm{BHI}$ logs}
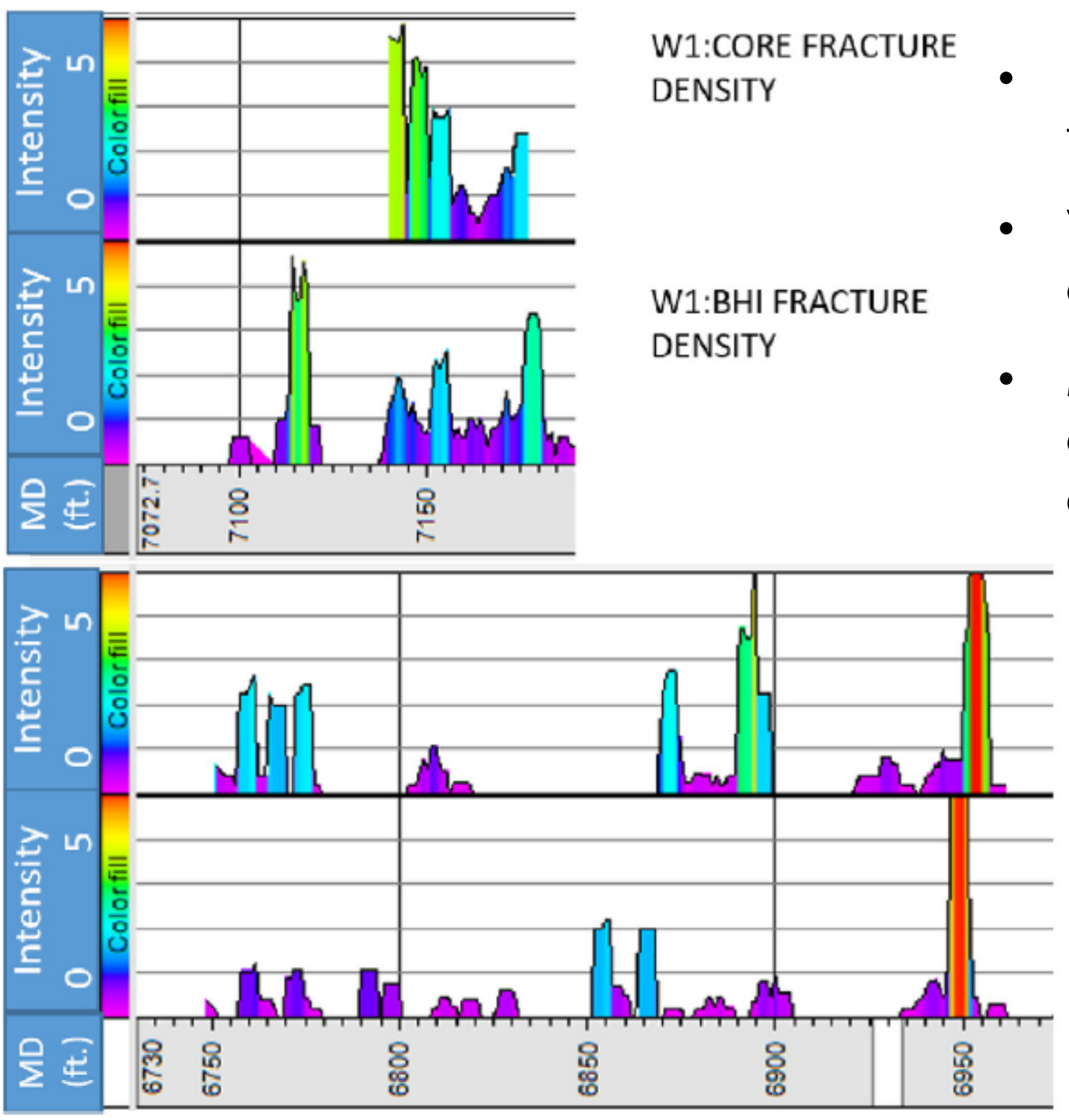

From Aabø et al. 2020
W1:CORE FRACTURE DENSITY

W1:BHI FRACTURE DENSITY
- Fractures picked on resistivity images from 7 wells, vertical and horizontal.

- Very high density: up to $5 \mathrm{fracs} / \mathrm{m}$, corrected for borehole orientation.

- Most of these are conductive - may correspond to small fractures seen on core.

W2:CORE FRACTURE DENSITY

W2:BHI FRACTURE DENSITY
- Also a few resistive or partially resistive fractures - may correspond to large cemented or slickensided fractures seen on core. 
Fractures picked on resistivity images from 7 wells, vertical and horizontal.

Two sets identified:

- NNE/SSW-striking regional set related to faults?

- Radial set parallel to contours of salt pillow generated by doming?

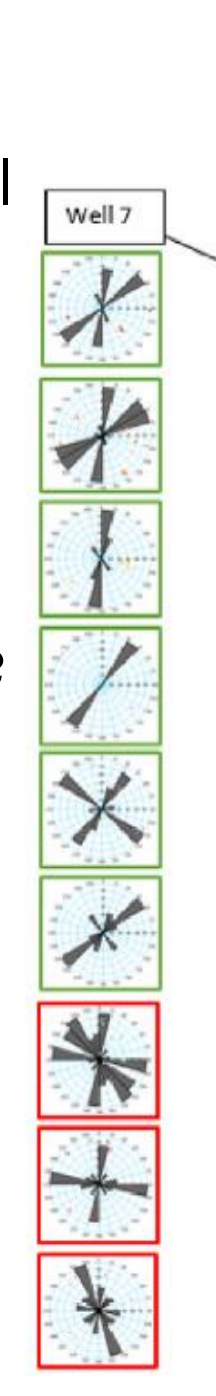

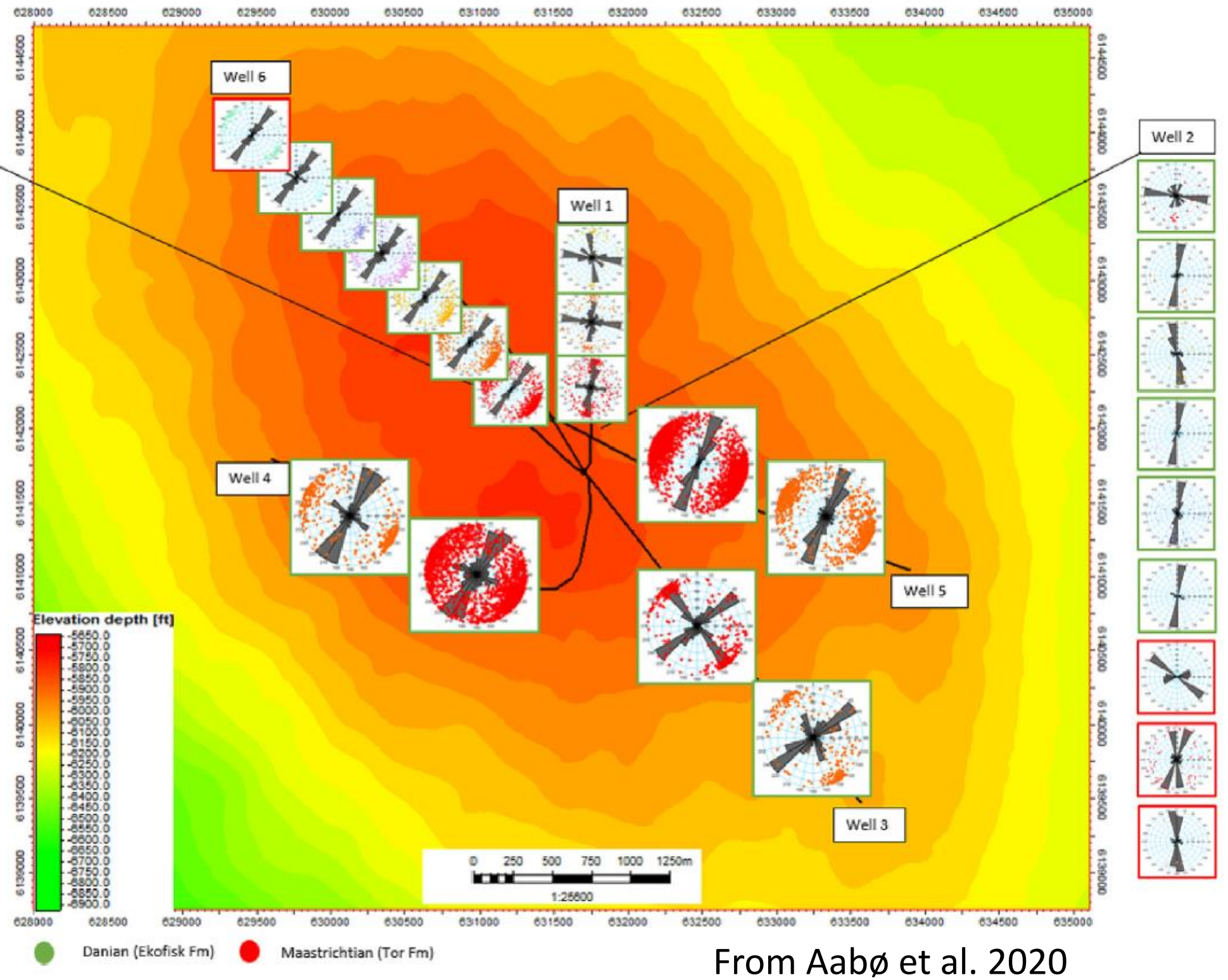




\section{Lineations on ant-tracked seismic data}

Conductive fractures

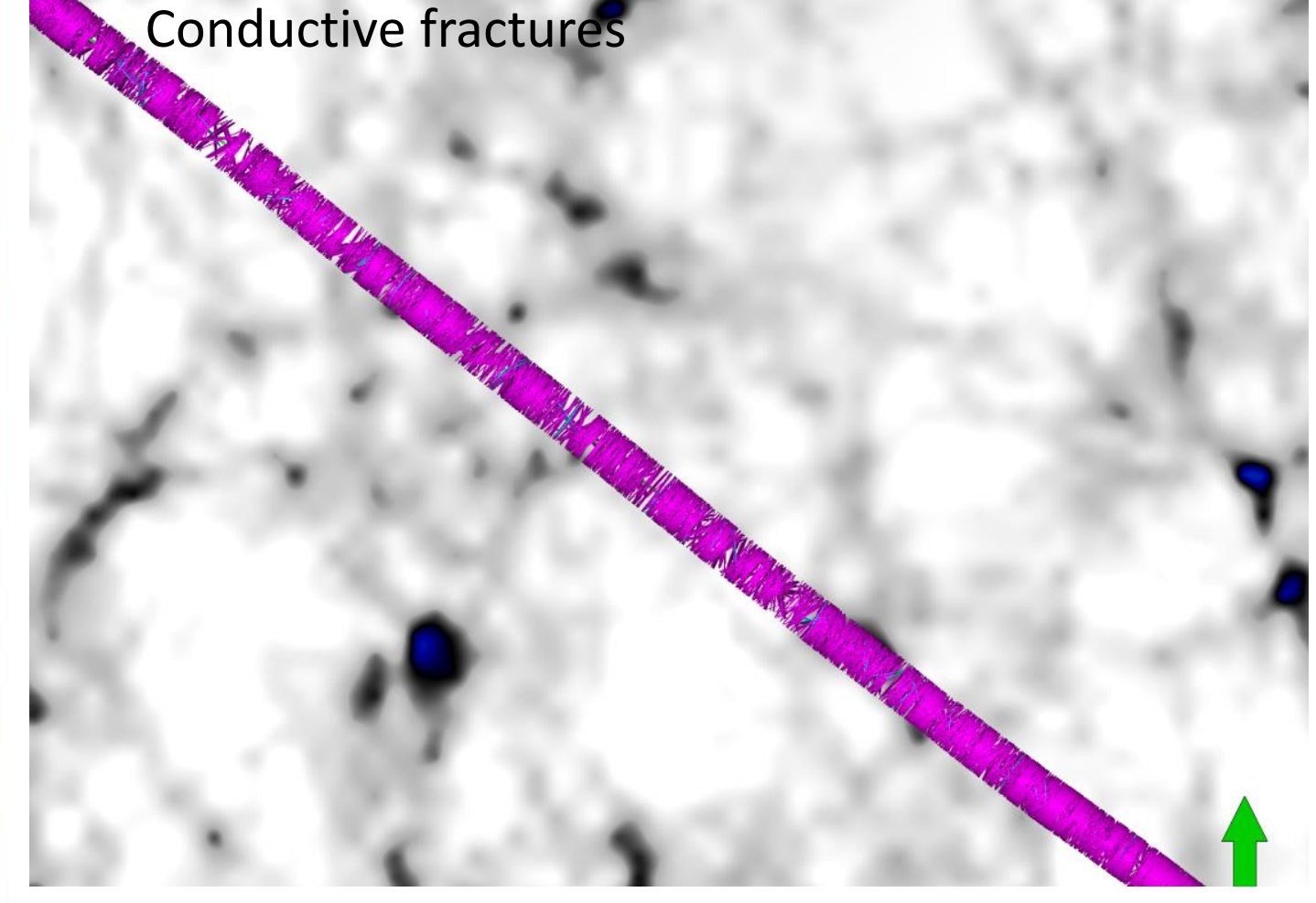

- These lineations correlate well with the density and orientation of the resistive fractures on $\mathrm{BHI}$ data.

- They may represent fracture corridors or damage zones around small faults.
- Seismic amplitude data was enhanced using eXchroma and ant-tracking algorithms to highlight subtle features.

- This process highlights subtle lineations in the Ekofisk Fm

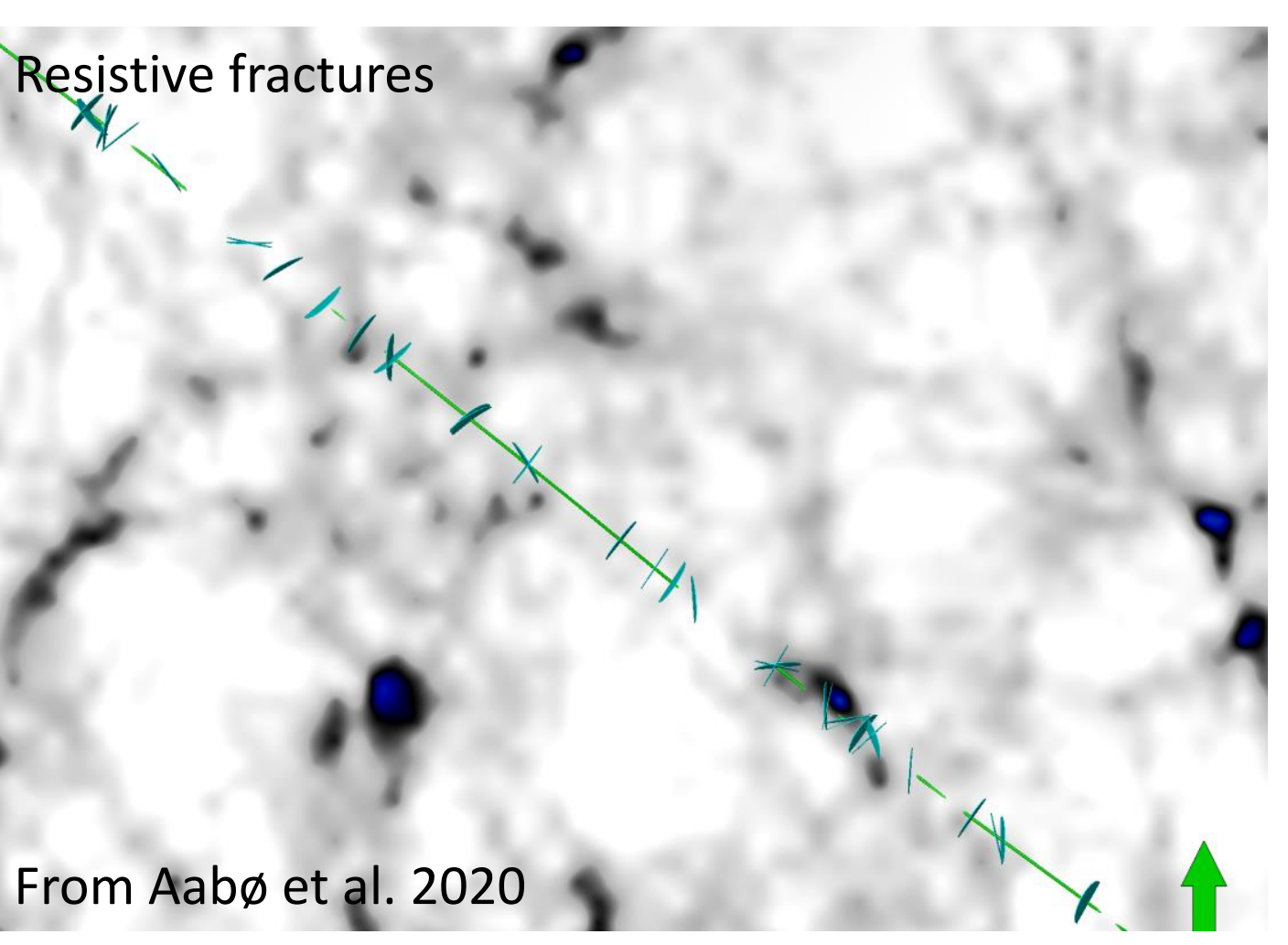




\section{Forward modelling fracture growth: Rationale}

- Fractures are key to fluid flow in the Ekofisk Fm, and must be included in flow models.

- This can be achieved either by modifying the bulk rock properties to take account of the fracture porosity and permeability, or by generating Discrete Fracture Network models (DFNs). In both cases, a more accurate representation of the distribution, orientation, length and connectivity of fractures in the subsurface will give a better history match.

- Traditional fracture modifiers and DFNs are based on stochastic techniques - fractures are placed at random and there is little constraint on length and connectivity. They therefore give poor results.

- We have built DFNs by simulating the nucleation and growth of the fractures, based on geomechanical principles and geological knowledge. We therefore generate much more realistic fracture models which honour the geology. 


\section{Forward modelling fracture growth:}

\section{Conceptual model}

- We start with a single planar, homogeneous layer.

- We model 2 types of fracture:

- Small, circular microfractures.

- Large, layer-bound macrofractures.

- We model interaction

between fractures:

- Stress shadow interaction of parallel fractures (A).

- Intersection of perpendicular or oblique fractures (B).

Key inputs:

- Strain history

- Mechanical properties

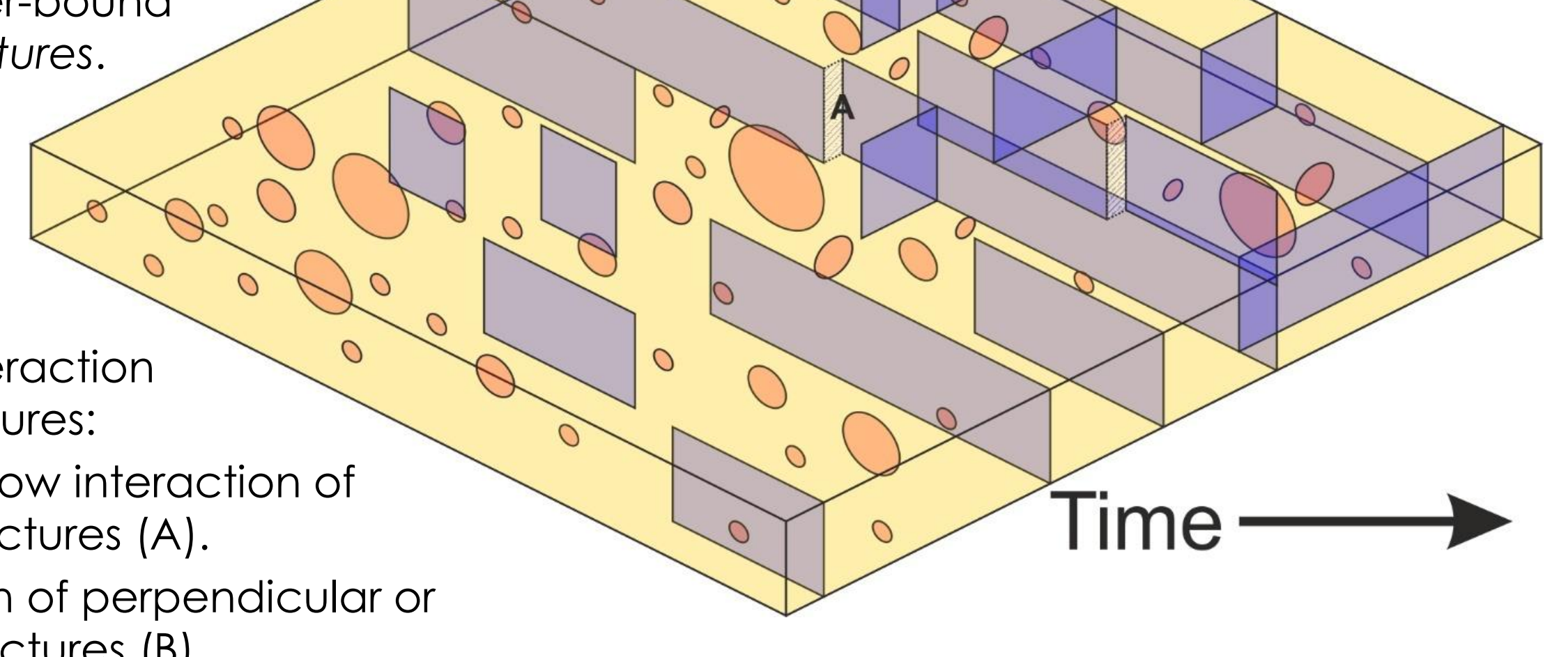




\section{Strain history: Regional extension}

- ESE/WNW extension, perpendicular to seismicscale faults.

- BEM used to calculate local stress anomalies around the seismic-scale faults.

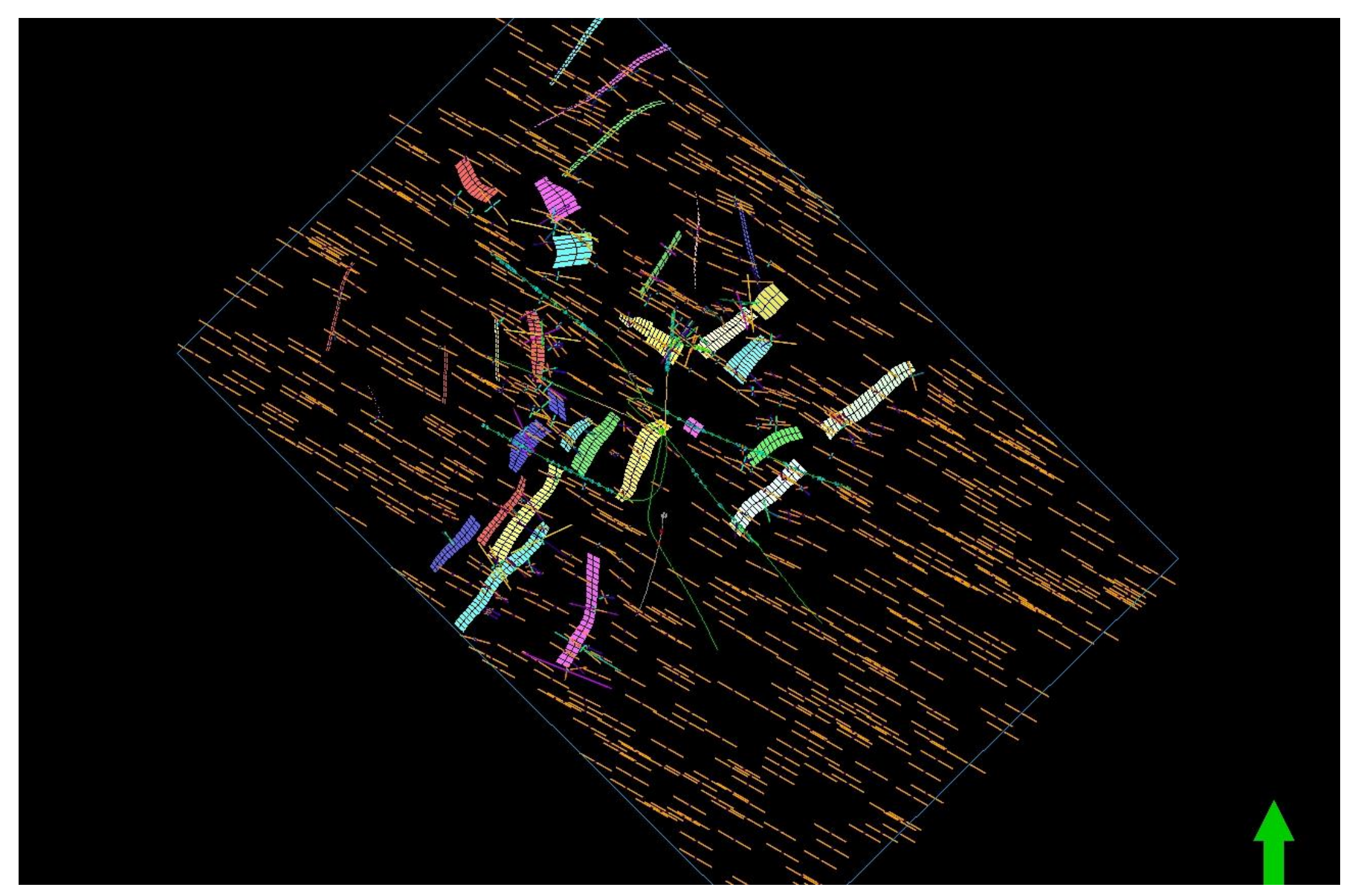


- Subsidence is calculated by backstripping the overburden.

- The resulting deformation tensor is differentiated to calculate flexural strain.

- Strain is highest on the flanks of the structure rather than at the crest.

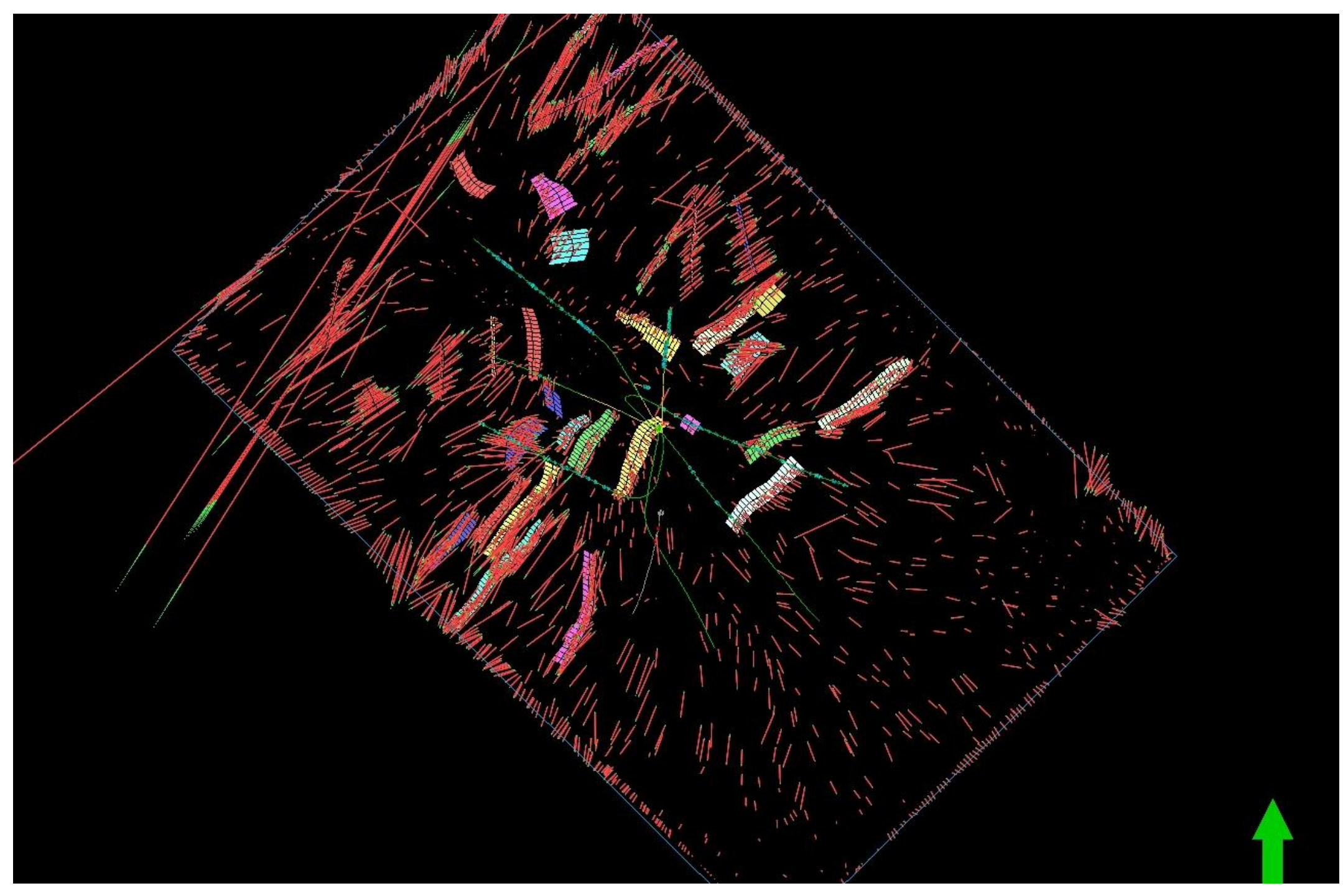




\section{Young's Modulus}

- Porosity is calculated from seismic inversion

- Young's Modulus is then calculated from porosity, using an empirical relationship derived from mechanical property test data.

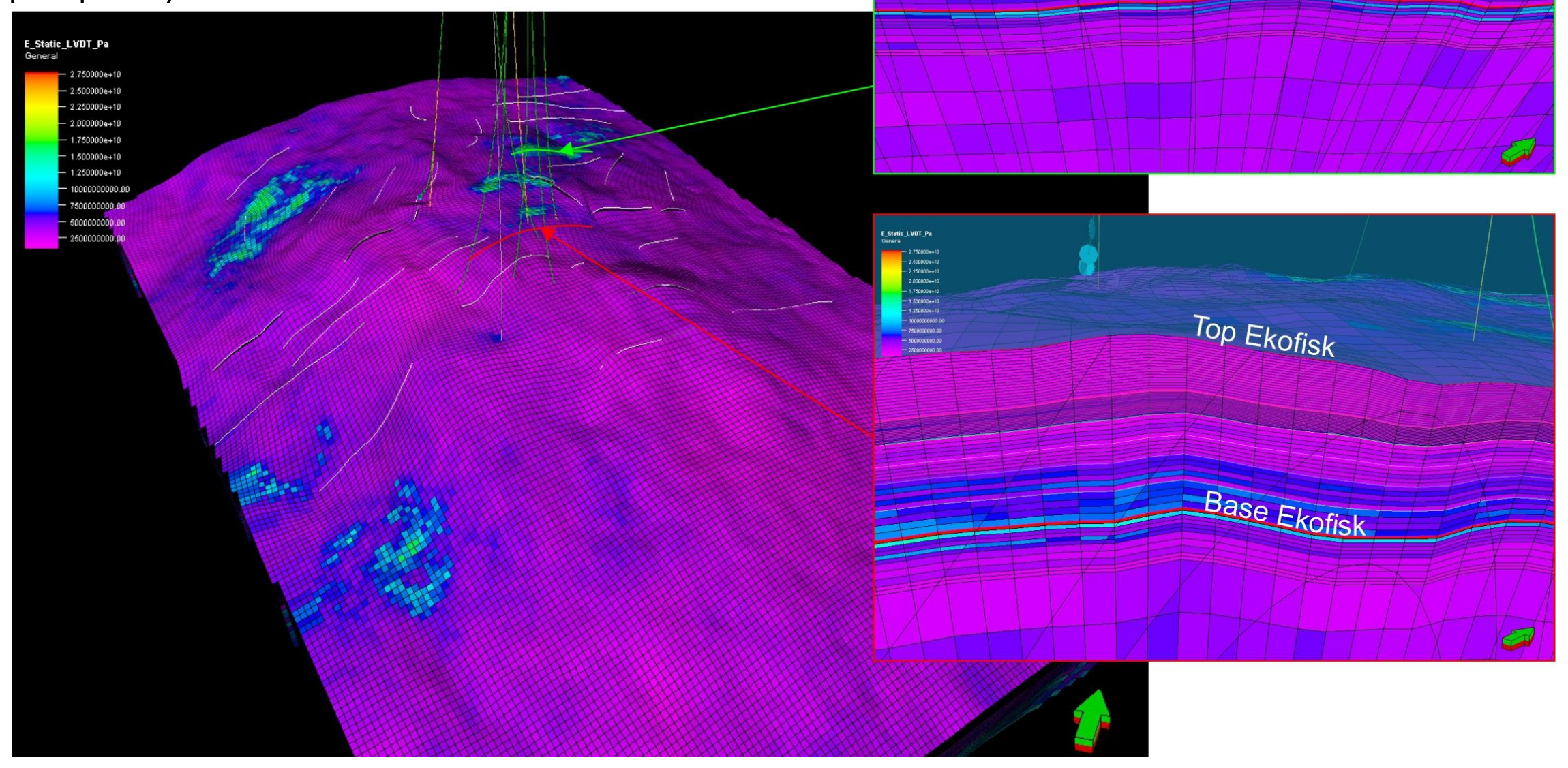


EAEE2020

ANNUAL CONFERENCE

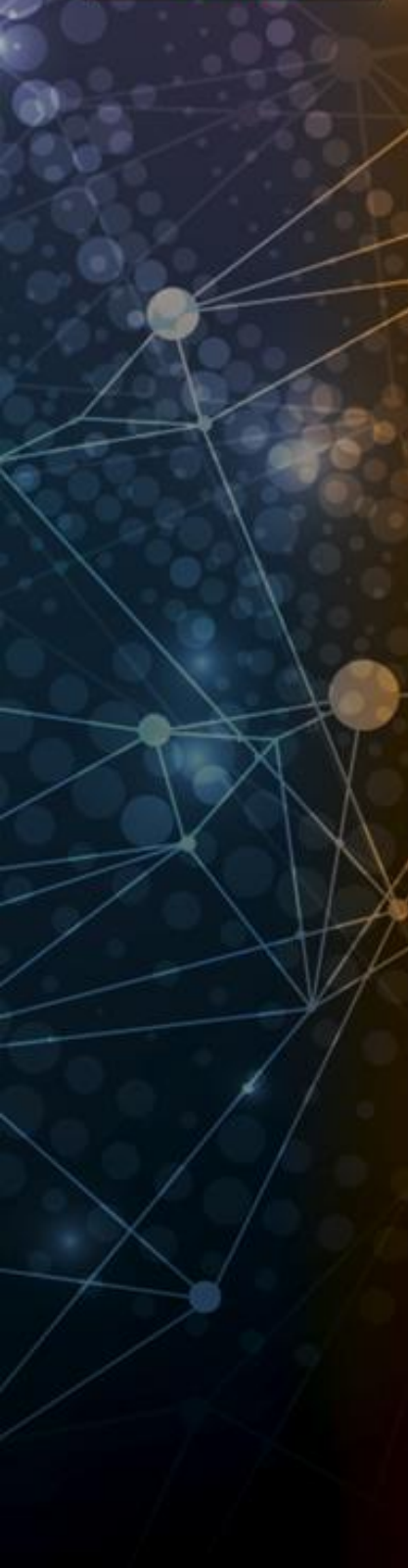

- Main control on fracture growth is strain.

- Fractures nucleate first in areas with highest strain rates - on the flanks of the dome.

- Young's Modulus is a minor controls.

- It may affect timing - fractures nucleate earlier in stiff zones but not final geometry.

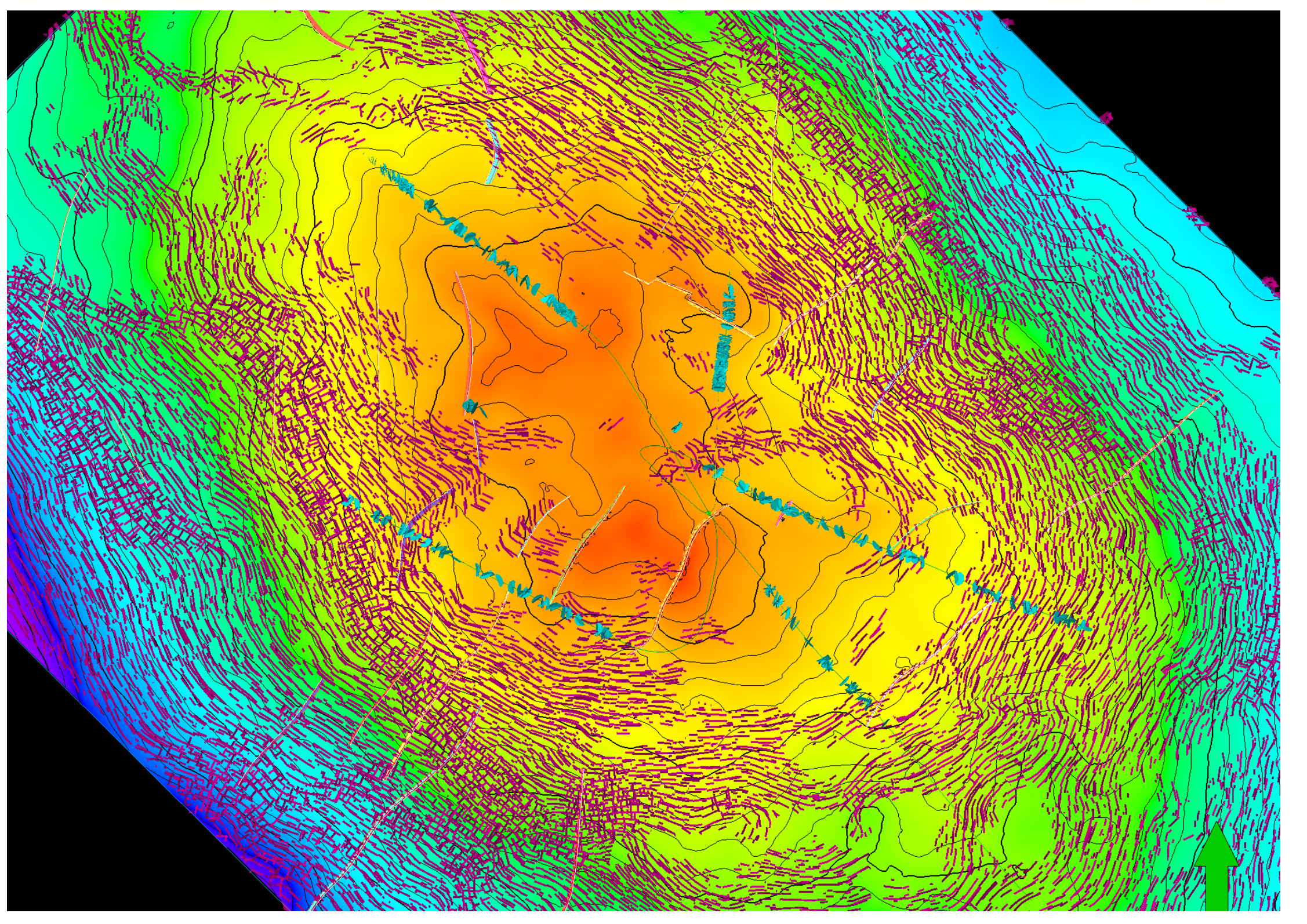


- The regional strain model gives a good fit with observed fracture orientation close to the faults.

- The match is less good away from the faults.

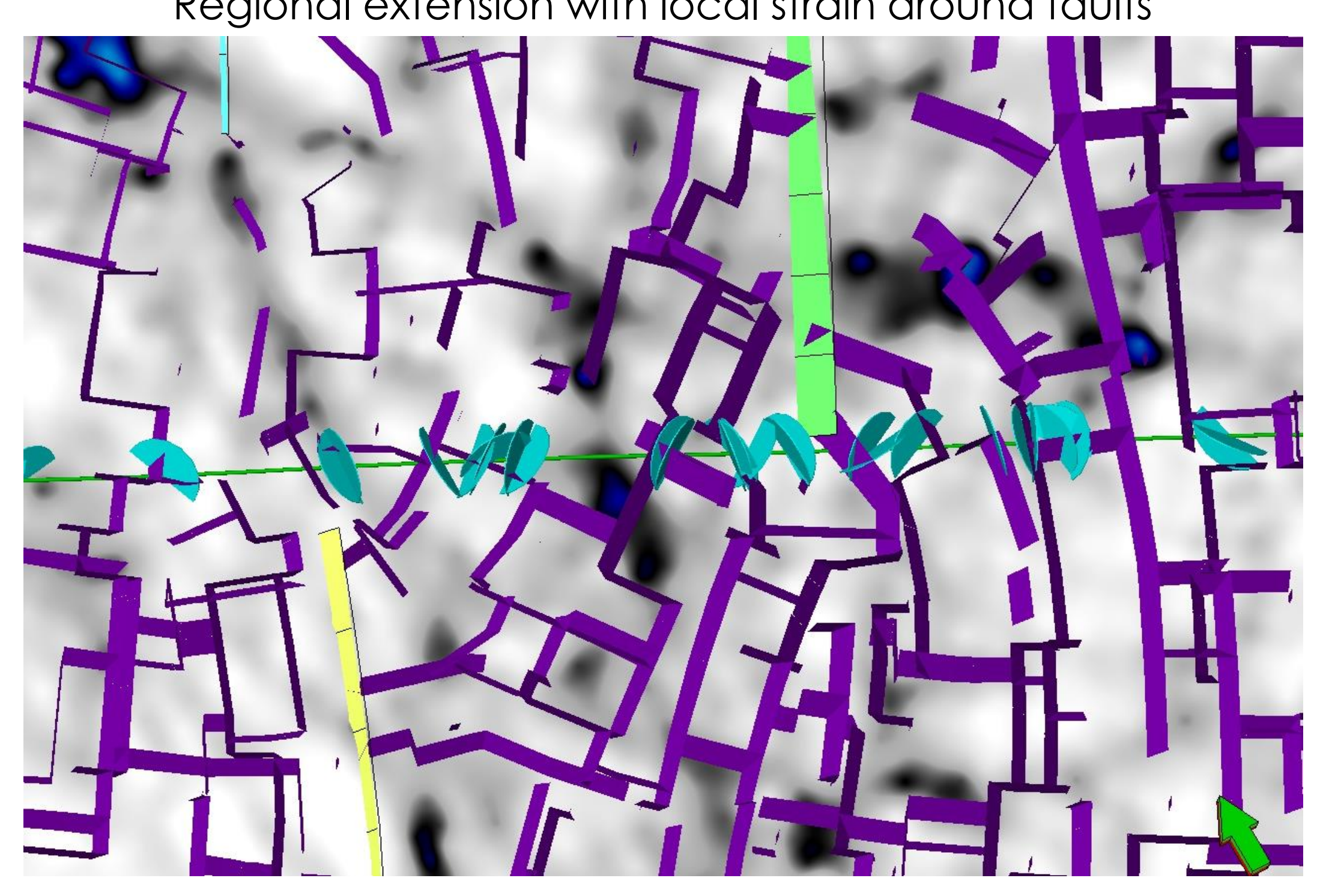


Regional extension with local strain around faults

- The regional strain model gives a good fit with observed fracture orientation close to the faults.

- The match is less good away from the faults.

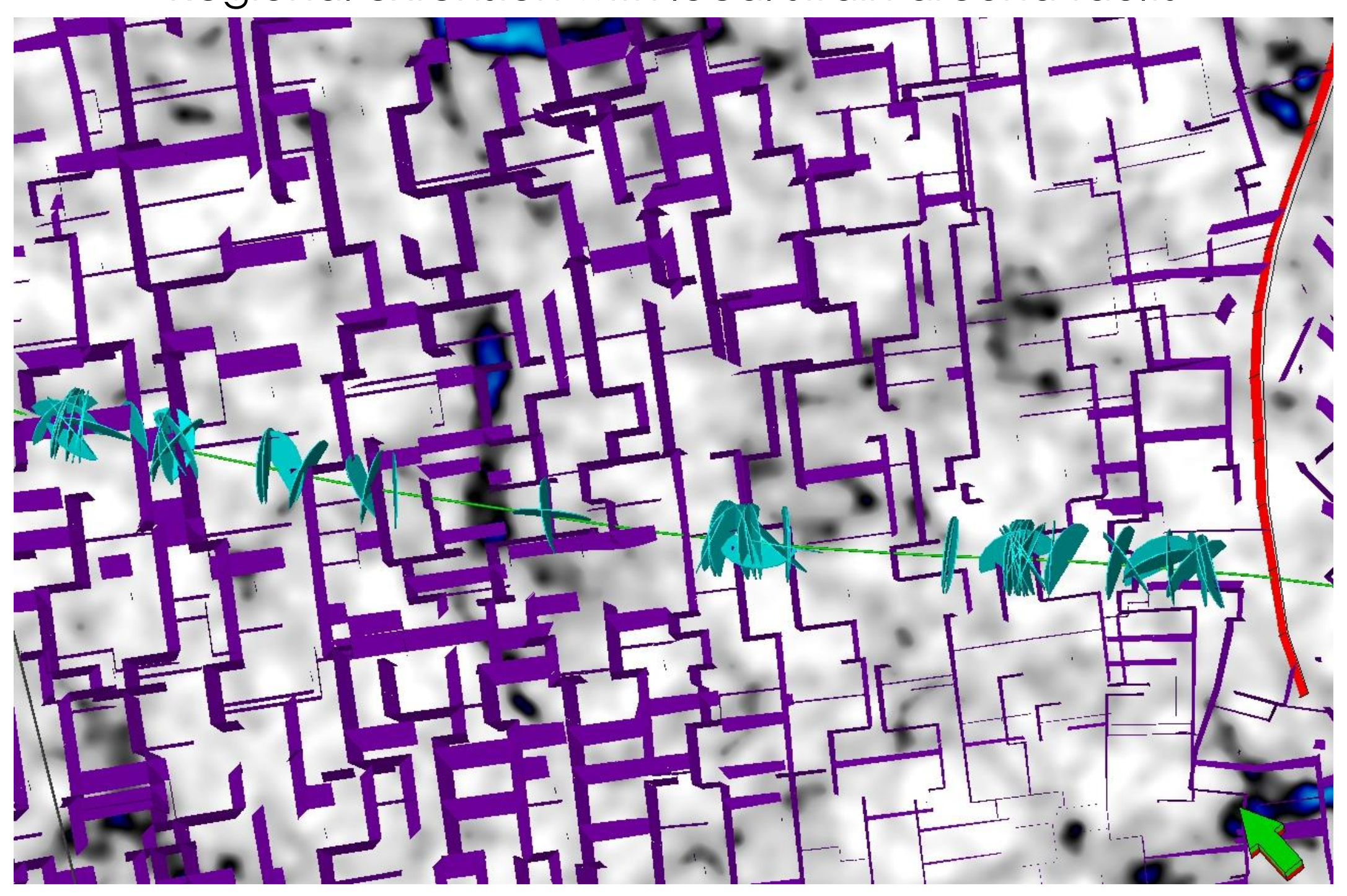




\section{Comparison of DFN with observed fractures}

Flexural extension related to doming

- The flexural strain model gives a better fit with observed fracture orientation away from the faults.

- Note the spacing of $\mathrm{BHI}$ fracture clusters and DFN fractures.

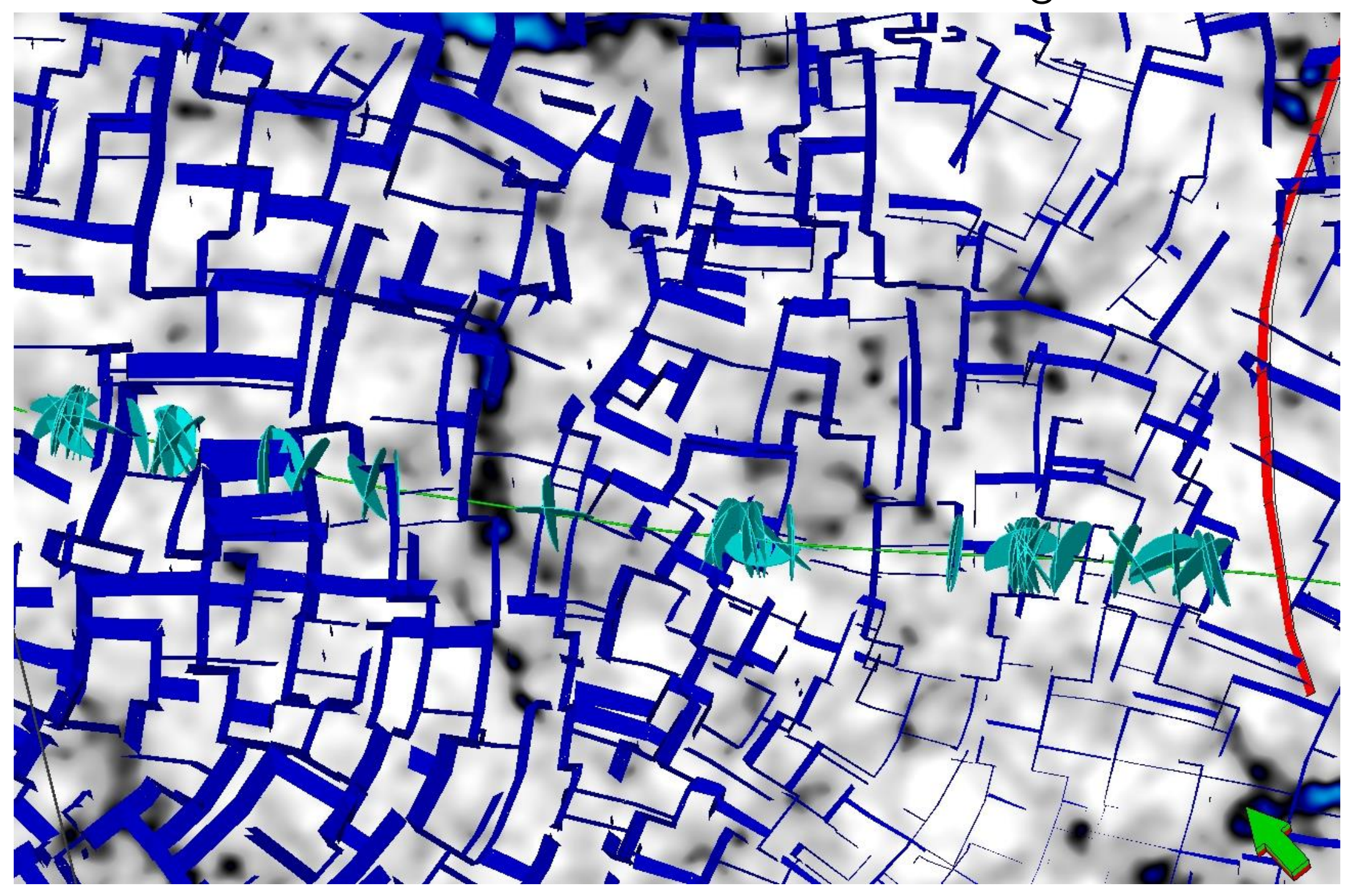


Flexural extension related to doming

- Purple disk represents large slickensided fracture from core.

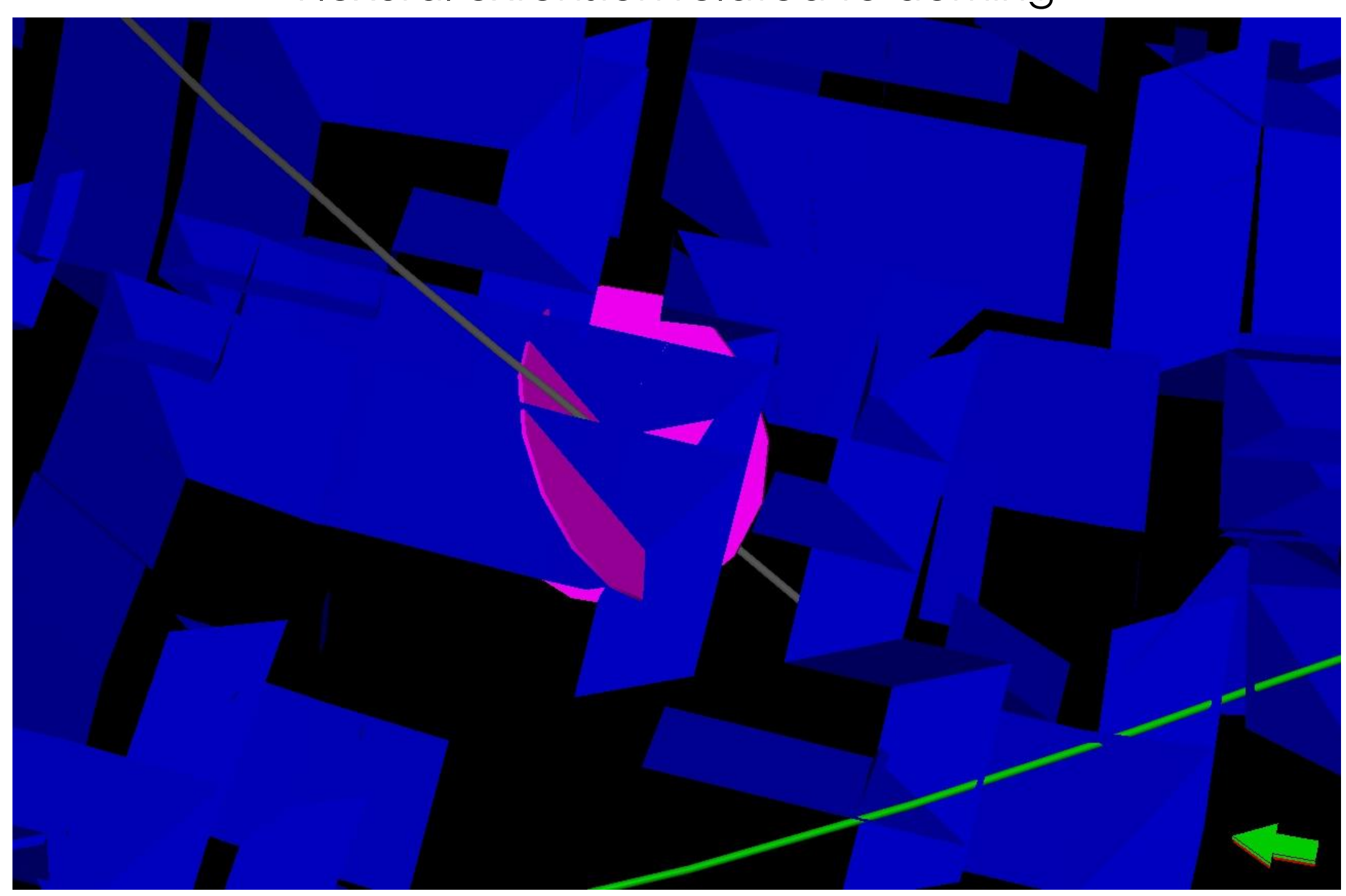




\section{Comparison of DFN with ant-tracked seismic}

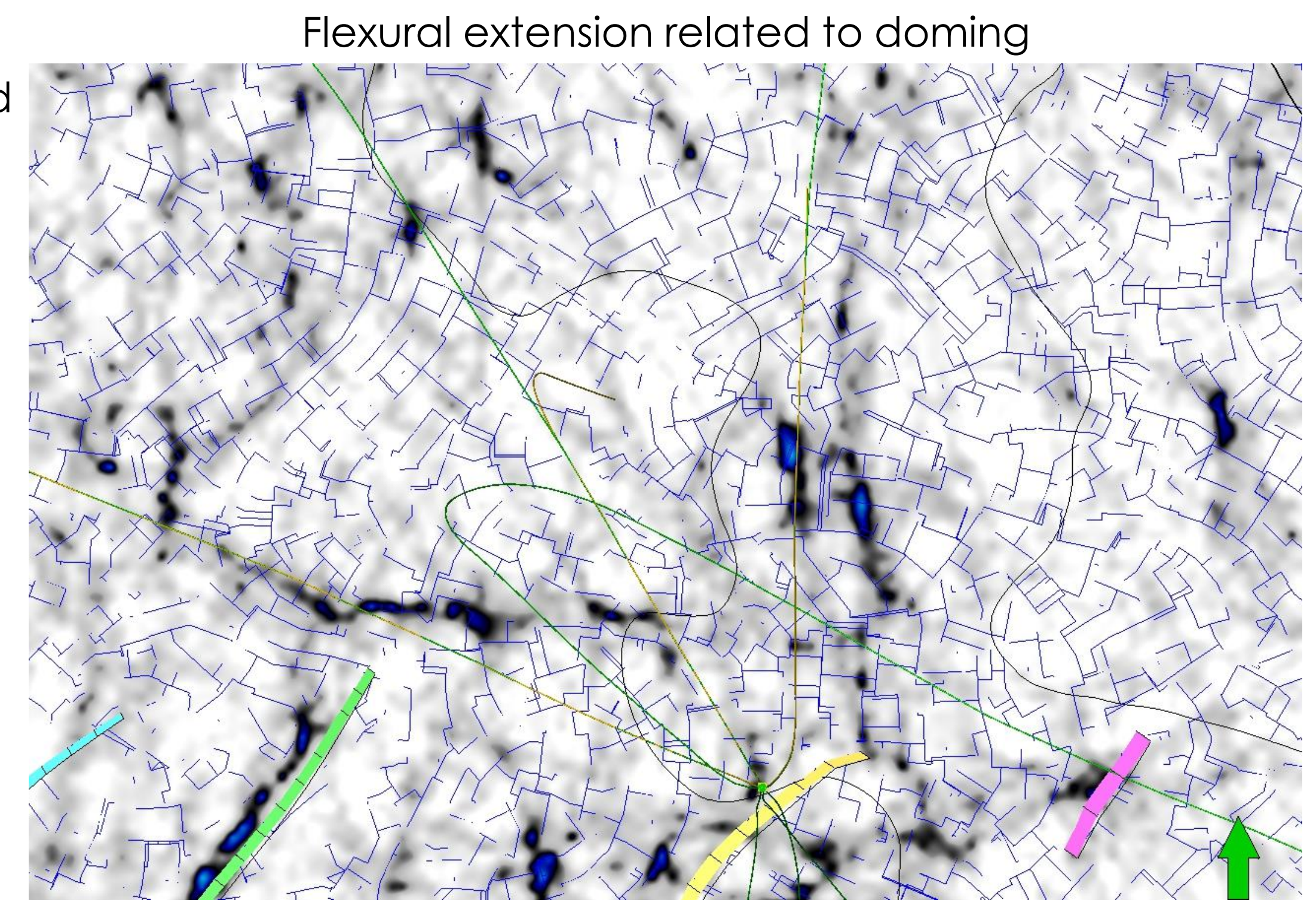

- There is a good match in orientation in some areas but significant discrepancies in other areas.

- Note the similarity in spacing and connectivity. 


\section{Comparison of DFN with ant-tracked seismic}

Flexural extension related to doming

- There is a good match in orientation in some areas but significant discrepancies in other areas.

- Note the similarity in spacing and connectivity.

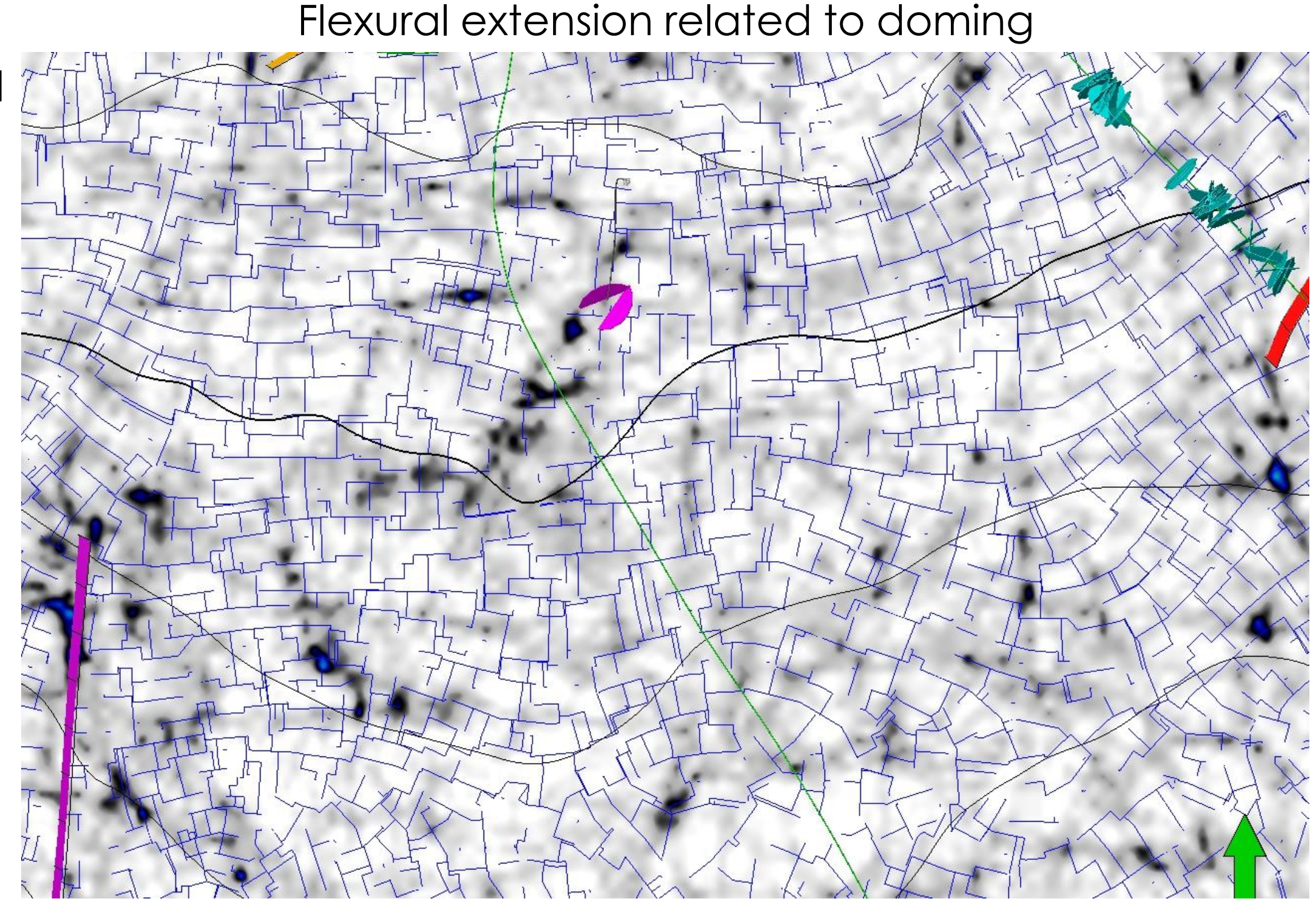




\section{Conclusions}

- We can generate a DFN that is consistent with observed fractures by forward modelling fracture growth.

- The layer-bound fractures in this DFN represent the large cemented or slickensided fractures observed in core.

- The smaller fractures observed in core, related to stylolites or chert nodules, may represent the "seed" microfractures.

- The key to accurate fracture prediction is getting the strain history correct.

- The ant-tracked seismic data may show similar patterns, although this is not certain. 
Application of Geomechanically-Based Fracture Models to a Fractured Chalk Field, Offshore Denmark 
Fracture orientation from BHI (Aabø et al. 2020)

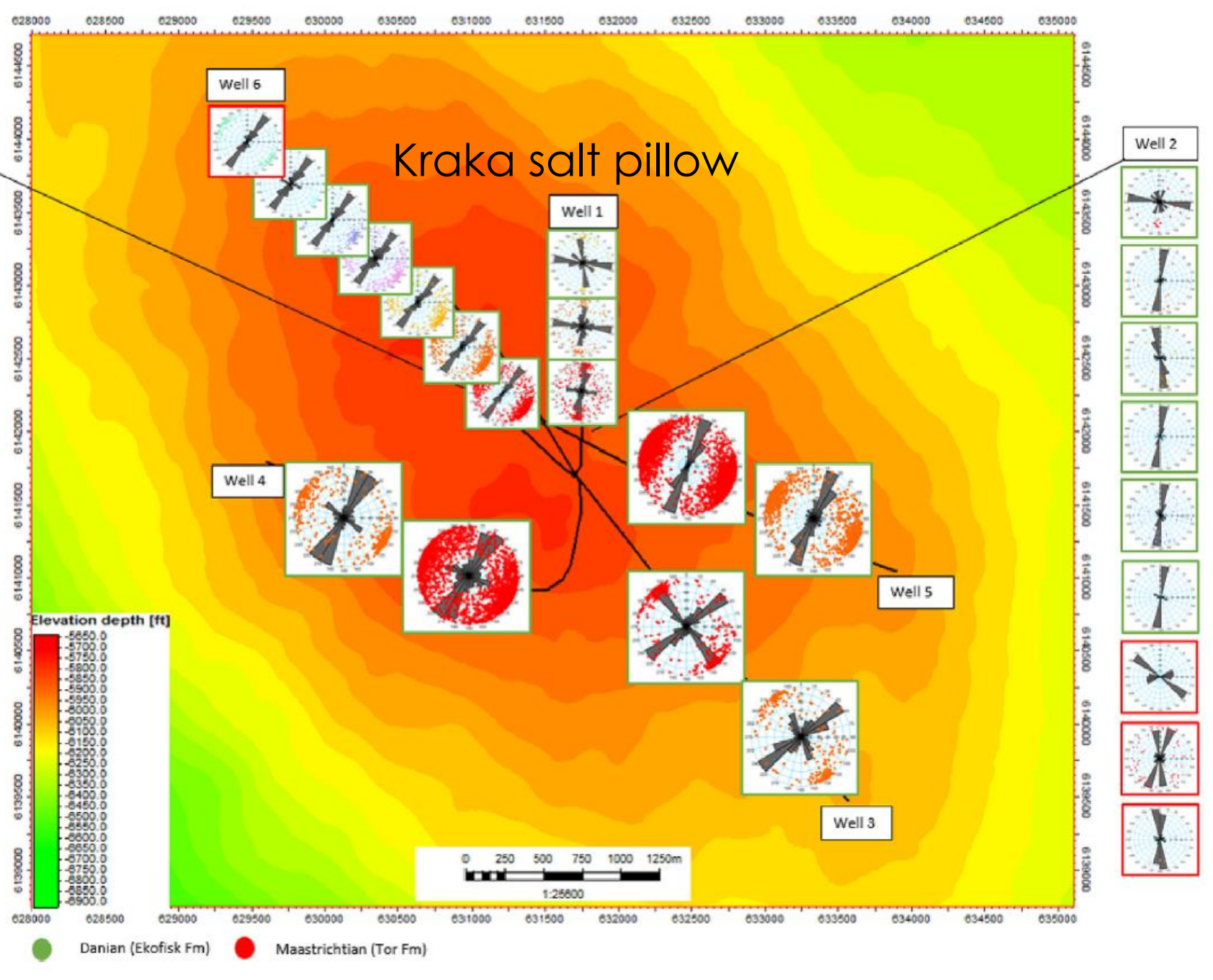

Fractures in core:

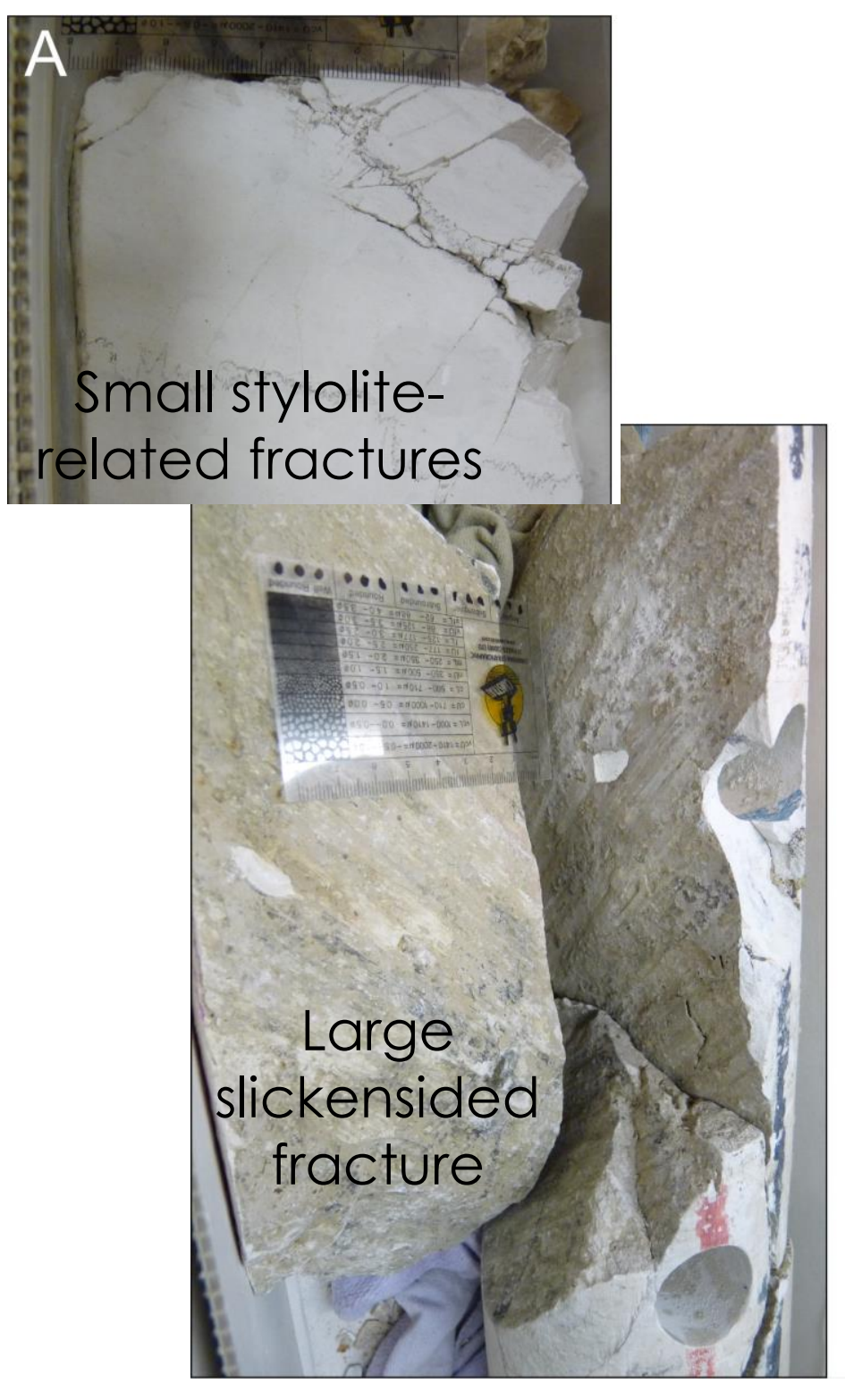




\section{Forward modelling fracture growth:}

\section{Conceptual model}

- We start with a single planar, homogeneous layer.

- We model 2 types of fracture:

- Small, circular microfractures.

- Large, layer-bound macrofractures.

- We model interaction

between fractures:

- Stress shadow interaction of parallel fractures (A).

- Intersection of perpendicular or oblique fractures (B).

Key inputs:

- Strain history

- Mechanical properties

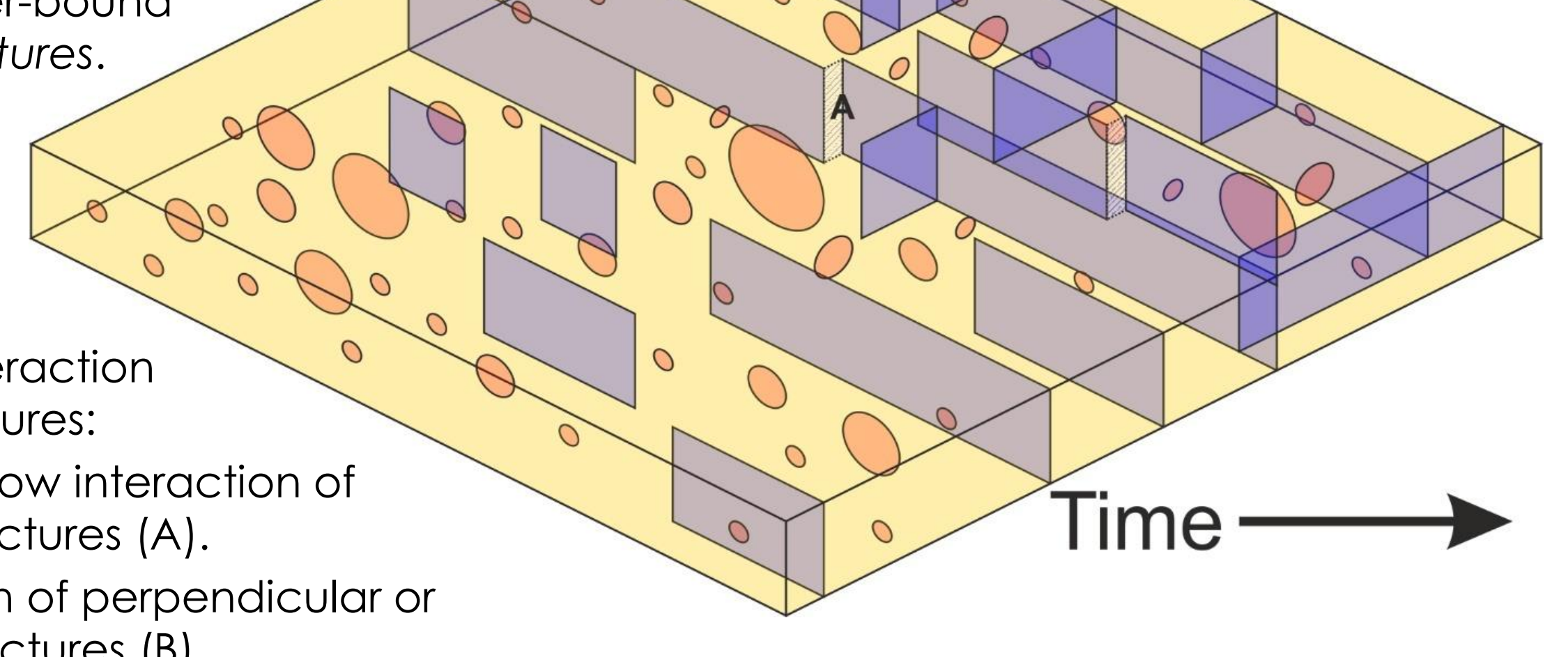




\section{Comparison of DFN with observed fractures}

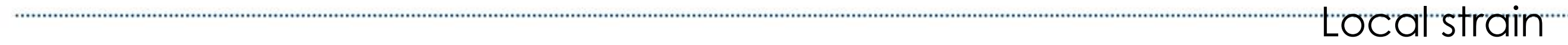

Flexural extension related to doming

- The flexural strain model gives a better fit with observed fracture orientation in most areas.

- Around the faults, a better match is obtained with the fault-related strain.

- Note the spacing of $\mathrm{BHI}$ fracture clusters and DFN fractures.

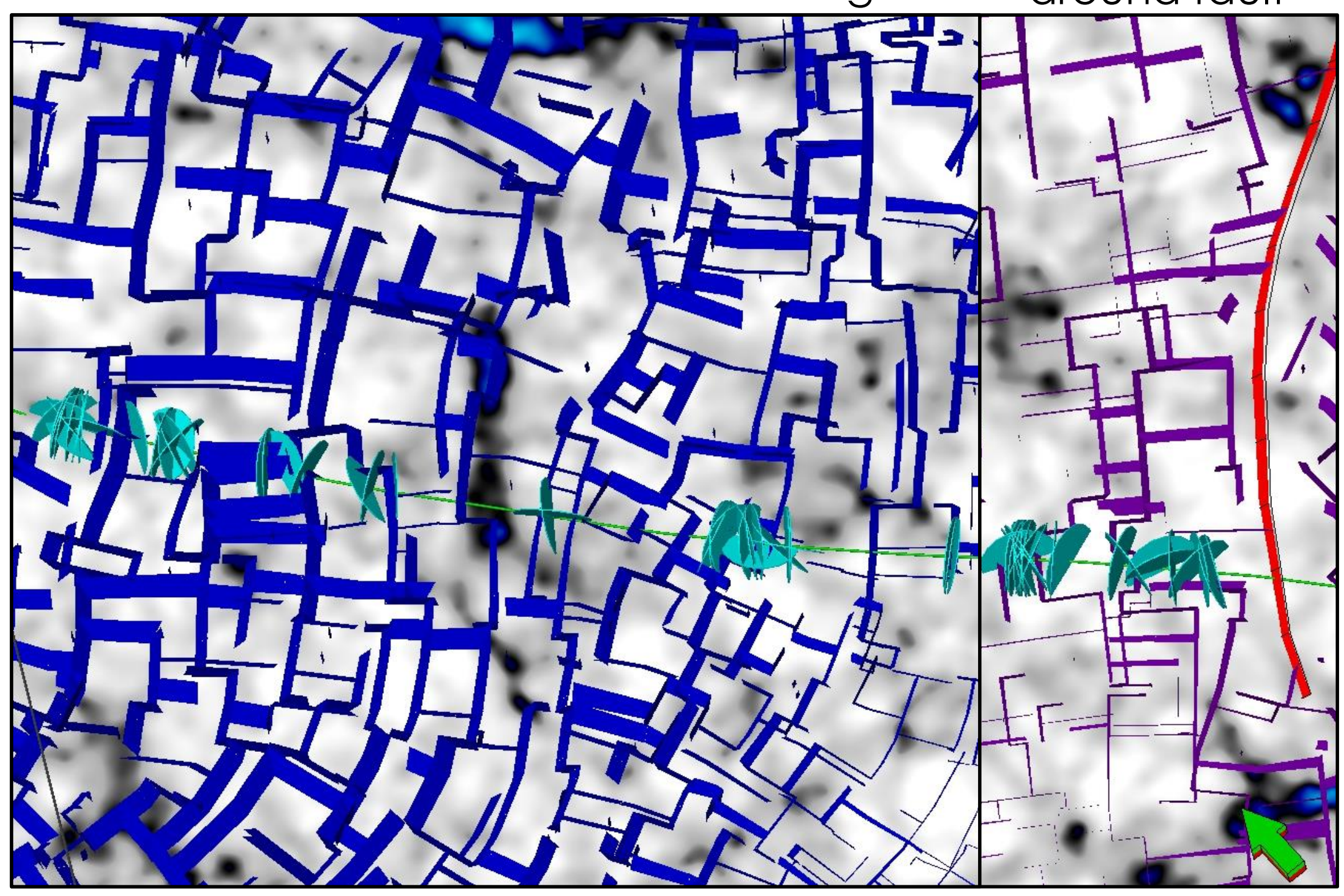

